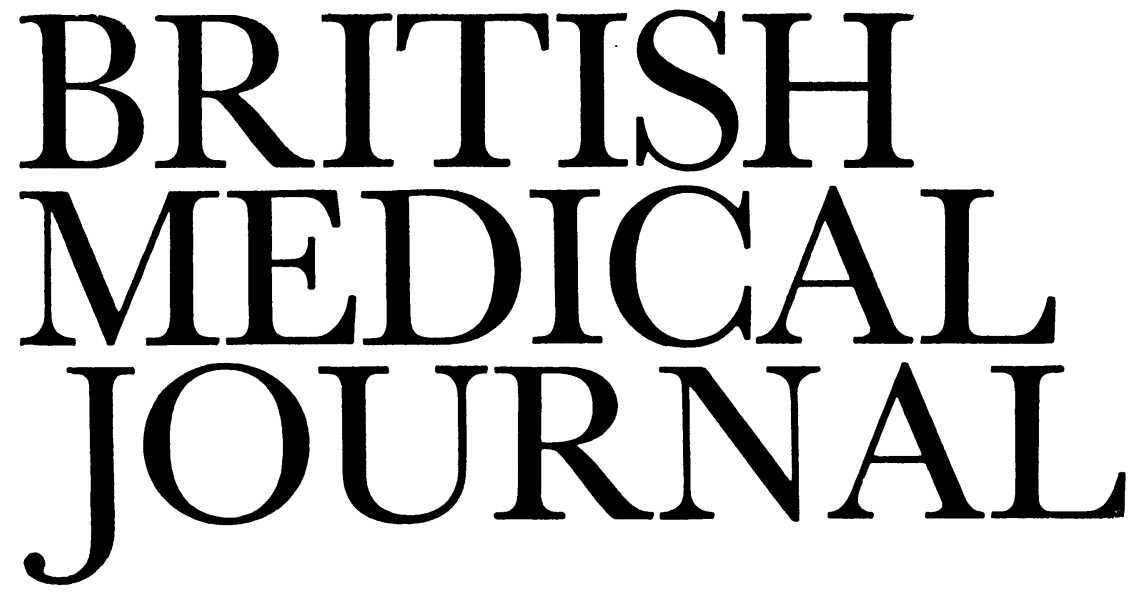

LONDON, SATURDAY 31 MARCH 1984

\title{
Maternal plasma volume and disorders of pregnancy
}

Maternal plasma volume increases progressively during the second and third trimesters of pregnancy. ${ }^{12}$ The extent of the increase depends on the size of the conceptus, tending to be most in women with multiple pregnancies, ${ }^{34}$ and least in women with babies small for gestational age. ${ }^{125}$ Maternal plasma volume is also reduced in women with pre-eclampsia, a common cause of impaired fetal growth, ${ }^{6}$ although factors other than fetal size may contribute to the maternal hypovolaemia. ${ }^{7-9}$ Pregnant women with chronic hypertension are another group who may have reduced plasma volumes (as do non-pregnant subjects with essential hypertension ${ }^{10}$ ), although in some studies it is not clear whether or not women with superimposed pre-eclampsia were excluded. ${ }^{911}$ Thus a raised blood pressure may directly reduce plasma volume, but in preeclampsia, a more important factor may be a low concentration of albumin in the plasma, which is characteristic of the disorder. ${ }^{1213}$ It is assumed that the hypoalbuminaemia is due to albumin loss in the urine, after proteinuria develops, although this has never been proved. The possibility that albumin may leak into the extravascular tissues through abnormally permeable capillaries has not been substantiated. ${ }^{14}$ In women with pre-eclampsia the total intravascular albumin mass is reduced, although extravascular albumin remains unchanged and neither the exchange of albumin between the two compartments nor its catabolic rate changes. ${ }^{15}$ Though the cause of the low plasma albumin is thus unexplained, its reduced concentration lowers plasma oncotic pressure ${ }^{16}$ and predisposes towards loss of fluid from the vascular compartment. This explains the formation of oedema in severe pre-eclampsia and identifies a process which may further reduce the circulating plasma volume.

Plasma volume may be measured by safe dye dilution techniques but these are invasive and not used routinely in clinical practice. Haemoconcentration, however, may be readily assessed by measuring the packed cell volume. This reflects plasma volume depletion provided that the total red cell mass is not also reduced by blood loss or anaemia. ${ }^{81718}$ Thus a high packed cell volume suggests hypovolaemia and increases the likelihood that there is placental insufficiency and impaired fetal growth. ${ }^{19}$

It has been claimed that the hypovolaemia associated with pre-eclampsia may be the cause of poor tissue and organ perfusion leading to a maternal condition resembling circula- tory shock. ${ }^{20}$ This is exacerbated by the increased blood viscosity which occurs in pre-eclampsia. ${ }^{21} 22$ Some workers have used plasma expanders to increase the plasma volume in such patients and claim that renal and possibly placental perfusion may be improved by such treatment. ${ }^{20} 2324$ Others disagree and point out that cardiac output is well maintained ${ }^{25}$ or even increase $d^{26}$ in pre-eclampsia and that, although the plasma volume is reduced, the capacity of the circulation may be reduced to a similar degree so that it is not underfilled. Sudden expansion of the plasma volume increases albumin loss from the capillaries into the extravascular space. ${ }^{27}$ If the infused plasma expanders (colloids) leak into the extravascular space the oedema will increase and dangerous complications such as pulmonary or laryngeal oedema may ensue. A further potential problem with this form of treatment is the possibility that hypervolaemia rather than hypovolaemia may occasionally complicate pre-eclampsia. ${ }^{28}$

Goodlin and his colleagues have recently reported the results of plasma volume determinations in 200 women with various complications of pregnancy. Their purpose was to determine if any simple clinical investigation could be used to identify those women with hypovolaemia. Some of the test results (renal function, packed cell volume, serum albumin concentration) are likely to correlate with plasma volume because they measure variables which are directly related. Others, such as the platelet count or changes in liver enzyme activities, should reflect the severity of abnormalities in the clotting system or in the liver in pre-eclampsia but are unlikely to be related directly to hypovolaemia. Not surprisingly, the authors conclude that no routine clinical measurement accurately identified the pregnant women with hypovolaemia; in other words, the only way to determine plasma volume is to do so directly. ${ }^{29}$

This report assumes that depletion of plasma volume is the cause, not the consequence, of both fetal growth impairment and the maternal systemic disturbances in pre-eclampsia. The authors state that "a major goal of antenatal care should be an expansion of plasma volume in pregnant women." This assumption is unproved but could be tested by a randomised controlled trial to see if expansion of the plasma volume has any beneficial effect on the outcome of pregnancy. No such study has yet been described. The importance of maternal plasma volume in disorders of pregnancy remains unclear. On present evidence, therefore, Goodlin's recommen- 
dation that plasma volume estimations should be a part of routine clinical investigation cannot be accepted.

\section{W G REDMAN}

Lecturer in Obstetric Medicine,

John Radcliffe Hospital,

Oxford OX3 9D4

' Hytten FE, Paintin DB. Increase in plasma volume during normal pregnancy. Fournal of Obstetrics and Gynaecology of the British Commonwealth 1963;70:402-7.

2 Pirani BBK, Campbell DM, MacGillivray I. Plasma volume in normal first pregnancy. Fournal of Obstetrics and Gynaecology of the British Commonwealth $1973 ; 80: 884-7$.

${ }^{3}$ Rovinsky JJ, Jaffin $\mathrm{H}$. Cardiovascular hemodynamics in pregnancy. I. Blood and plasma volumes in multiple pregnancy. Am $\mathcal{Y}$ Obstet Gynecol 1965;93:1-15.

4 Fullerton WT, Hytten FE, Klopper AI, McKay E. A case of quadruplet pregnancy. Fournal of Obstetrics and Gynaecology of the British Commonwealth $1965 ; 72: 791-6$.

${ }^{5}$ Duffus GM, MacGillivray I, Dennis KJ. The relationship jetween baby weight and changes in maternal weight, total body water, plasma volume, electrolytes and proteins and urinary oestriol excretion. fournal of Obstetrics and Gynaecology of the British Commonwealth 1971;78:97104.

${ }^{6}$ Gruenwald P. Growth of the human fetus. II. Abnormal growth in twins and infants of mothers with diabetes, hypertension, or isoimmunization. Am f Obstet Gynecol 1966;94:1120-32.

7 Cope I. Plasma and blood volume changes in pregnancies complicated by pre-eclampsia. Fournal of Obstetrics and Gynaecology of the British Commonwealth $1961 ; 68: 413-6$.

${ }^{8}$ Chesley LC. Plasma and red cell volumes during pregnancy. Am $\mathcal{f}$ Obstet Gynecol 1972;112:440-50.

${ }^{9}$ Bing RF, Smith AJ. Plasma and interstitial volumes in essential hypertension: relationship to blood pressure. Clin Sci 1981;61:287-93.

${ }^{10}$ Gallery EDM, Hunyor SN, Györy AZ. Plasma volume contraction: a significant factor in both pregnancy-associated hypertension (preeclampsia) and chronic hypertension in pregnancy. $Q \mathcal{F}$ Med 1979;48: 593-602.

${ }^{11}$ Arias F. Expansion of intravascular volume and fetal outcome in patients with chronic hypertension and pregnancy. Am J Obstet Gynecol 1975; $123: 610-6$.

${ }^{12}$ Studd JWW, Blainey JD, Bailey DE. Serum protein changes in the preeclampsia-eclampsia syndrome. Fournal of Obstetrics and Gynaecology of the British Commonwealth 1970;77:796-801.

${ }^{13}$ Horne CHW, Howie PW, Goudie RB. Serum alpha ${ }_{2}$-macroglobulin, transferrin, albumin, and IgG levels in preeclampsia. $\mathcal{F}$ Clin Pathol $1970 ; 23: 514-6$.

${ }^{14}$ Chesley LC. Hypertensive disorders in pregnancy. New York: AppletonCentury-Crofts, 1978:215-9.

${ }^{15}$ Henshall WR. Differences in albumin distribution and dynamics between toxaemic and non-toxaemic pregnant women. Br $\mathcal{f}$ Obstet Gynaecol $1979 ; 86: 463-7$

${ }^{16}$ Benedetti TJ, Carlson RW. Studies of colloid osmotic pressure in pregnancy-induced hypertension. Am F Obstet Gynecol 1979;135:308-11.

17 Liley AW. Clinical and laboratory significance of variations in maternal plasma volume in pregnancy. Int $\mathcal{f}$ Gynaecol Obstet 1970;8:358-62.

${ }^{18}$ Lund CJ, Donovan JC. Blood volume during pregnancy. Significance of plasma and red cell volumes. Am F Obstet Gynecol 1967;98:393-403.

19 Koller O, Sandvei R, Sagen N. High haemoglobin levels during pregnancy and fetal risk. Int f Gynaecol Obstet 1980;18:53-6.

${ }^{20}$ Cloeren SE, Lippert TH. Effect of plasma expanders in toxemia of pregnancy. N Engl f Med 1972;287:1356-7.

${ }^{21}$ Hobbs JB, Oats JN, Palmer AA, et al. Whole blood viscosity in preeclampsia. Am $\mathcal{F}$ Obstet Gynecol 1982;142:288-92.

${ }^{22}$ Buchan PC. Preeclampsia-a hyperviscosity syndrome. Am $\mathcal{f}$ Obstet Gynecol 1982;142:111-2.

${ }^{23}$ Brewer TH. Administration of human serum albumin in severe acute toxaemia of pregnancy. Fournal of Obstetrics and Gynaecology of the British Commonwealth 1963;70:1001-4.

${ }^{24}$ MacLean AB, Doig JR, Aickın DR. Hypovolaemia, pre-eclampsia and diuretics. Br $\mathcal{F}$ Obstet Gynaecol 1978;85:597-601.

${ }^{25}$ Assali NS, Holm LW, Parker HR. Systemic and regional hemodynamic alterations in toxemia. Circulation 1964;29, 30, suppl 11:53-7.

${ }^{26}$ Hamilton HFH. Cardiac output in hypertensive toxaemias of pregnancy. fournal of Obstetrics and Gynaecology of the British Empire 1951; 58:977-84.

${ }^{27}$ Parving H-H, Rossing N, Nielsen SL, Lassen NA. Increased transcapillary escape rate of albumin, $\mathrm{IgG}$, and $\mathrm{IgM}$ after plasma volume expansion. Am F Physiol 1974;227:245-50.

${ }^{28}$ Goodlin R, Holdt D, Woods R. Pregnancy-induced hypertension associated with hypervolemia: case report. Am $\mathcal{F}$ Obstet Gynecol 1982;142: 114-5.

29 Goodlin RC, Dobry CA, Anderson JC, Woods RE, Quaife M. Clinical signs of normal plasma volume expansion during pregnancy. Am f Obstet Gynecol 1983;145:1001-9.

\section{Changing American medicine}

Dramatic changes are taking place in American medicine. In October 1983 the United States government changed the way it reimburses hospitals for Medicare patients (those aged over 65), but the change will eventually affect patients of all ages. The full effects of this new method of reimbursement will become apparent only with time, but the initial reaction of the health professions does allow speculation on the future of medicine in the United States.

By tradition doctors have been accustomed to using their discretion and judgment both in diagnosing and treating patients and in billing for their services. Hospital charges were designed to cover their costs and to generate a modest surplus. In 1965 the United States government introduced Medicare. Hospitals were reimbursed under part A, "covering reasonable costs," and doctors were allowed to make a "reasonable charge" under part B. As might have been predicted, the absence of reimbursement ceilings led to inflation at a rate considerably greater than in other sectors of the economy - though much of the increased cost was due to increased services. In 1983 health care costs in the United States had risen to $\$ 300$ billion ( $£ 200000$ million) a year, over $10 \%$ of the gross national product. The United States government pays for $40 \%$ and large employers $30 \%$ of the total bill for health care.

Recent changes in the health market place are now exerting pressure on the providers. The demand for hospital beds is diminishing; fewer were occupied in 1982 than 1981. Hospitals generally are losing their monopoly on many forms of health care-and thus are experiencing an erosion of their economic base. For example, much simple surgery is now performed in "surgicenters," which are not necessarily affiliated with hospitals. There is now an excess of doctors in the United States, 18000 new graduates having entered medical practice in 1983 alone. Doctors' net disposable incomes have declined steadily since 1975 . American consumers believe that they have a right to good health care and a right to live. They have come to expect expensive, high technical diagnostic procedures (such as computed tomography) and therapeutic measures such as coronary bypass surgery, renal dialysis, and transplants. Malpractice suits are increasing, pushing insurance premiums ever higher. Doctors are being forced to practise expensive defensive medicine. The United States population is aging and so making increasing demands on the delivery of health care.

In 1982 the United States government responded to pressure to control the costs of health care by passing the Tax Equity and Financial Responsibility Act, which-for the first time-placed a ceiling on reimbursement of hospital costs and redefined the doctors' services which were reimbursable as a hospital cost. The mechanism chosen to accomplish this goal was a system of prospective payments based on diagnosis related groups-a comprehensive set of 467 medical classifications initially developed at Yale University. Hospitals will now be reimbursed for each individual patient's stay at a rate determined by the discharge diagnosis; the actual length and cost of the stay are not taken into account. The sum paid for each diagnostic group is determined by a branch of the United States government, the Health Care Financing Administration. A three year phasing in period has begun, during which reimbursement will be shifted gradually from an emphasis on the hospital's costs, via a rate structure based on nine geographic regions, to a strict 